\title{
Prediksi Tingkat Kenyamanan Termal Kota Pontianak Menggunakan Jaringan Saraf Tiruan
}

\author{
Riska Dewi ${ }^{a^{*}}$, Yudha Armanª, Arie A. Kushadiwijayanto ${ }^{b}$ \\ aProgram Studi Geofisika, Universitas Tanjungpura, Pontianak \\ bProgram Studi Ilmu Kelautan, Universitas Tanjungpura, Pontianak \\ *Email : riskadewi@student.untan.ac.id
}

(Diterima 14 Oktober 2020; Disetujui 2 Desember 2020; Dipublikasikan 14 Desember 2020)

\begin{abstract}
Abstrak
Prediksi tingkat kenyamanan termal Kota Pontianak berdasarkan nilai Temperature Humidity Index (THI) telah dilakukan menggunakan jaringan syaraf tiruan propagasi balik (JSTPB). Data bulanan kelembapan dan suhu udara pada tahun 2009 hingga 2018 digunakan sebagai masukan bagi proses pelatihan jaringan, sementara proses validasi menggunakan data bulanan unsur udara yang sama pada tahun 2019. Arsitektur jaringan yang digunakan untuk unsur kelembapan udara adalah 12 lapisan masukan, 40 lapisan tersembunyi, dan 1 (satu) lapisan keluaran, sementara untuk suhu udara terdiri dari 12 lapisan masukan, 30 lapisan tersembunyi dan 1 (satu) lapisan keluaran. Jaringan yang dibentuk menghasilkan koefisien korelasi kelembapan udara dan suhu udara masing-masing sebesar 0,90 dan 0,91 dan diklasifikasikan sebagai berkorelasi sangat kuat. Nilai THI rata - rata tahunan yang dihitung menggunakan data-data unsur udara tersebut adalah $24,83^{\circ} \mathrm{C}$. Hasil tersebut menunjukkan bahwa secara rata-rata $50 \%$ populasi warga di Kota Pontianak merasakan kondisi termal yang nyaman. Terdapat beberapa bulan yang menunjukkan sebanyak $100 \%$ populasi merasakan hal yang sama, yaitu pada bulan Juni, Agustus, Oktober, dan Desember.
\end{abstract}

Kata kunci: Jaringan Saraf Tiruan, Propagasi Balik, Temperature Humidity Index

\section{Latar Belakang}

Temperature Humidity Index (THI) merupakan salah satu cara yang digunakan untuk mengetahui adanya perubahan termal serta menetapkan pengaruh dari keadaan termal tersebut di suatu wilayah [1]. Nilai THI juga biasa dimanfaatkan dalam kegiatan perancangan bangunan dan pengembangan arsitektur pembangunan di perkotaan [2]. Indeks tersebut juga sudah banyak digunakan untuk mengetahui tingkat kenyamanan termal di wilayah tropis seperti di daerah DKI Jakarta dan kota - kota besar Pulau Sulawesi $[3,4]$. Dari kajian tersebut diketahui bahwa tingkat kenyamanan akan semakin besar jika berada semakin jauh dari pusat kota [4]. Selain itu, THI hanya menjadi indeks hasil kontribusi dari beberapa parameter cuaca seperti suhu udara dan kelembapan udara.

Parameter cuaca yang berkontribusi terhadap indeks THI diketahui sangat dinamis. Data - data yang dipublikasi oleh lembaga terkait menunjukkan variasi yang cukup kompleks terutama di wilayah Kota Pontianak, Kalimantan Barat yang dilalui oleh garis Equator. Prediksi keadaan cuaca dengan kondisi sangat dinamis tersebut umumnya dilakukan dengan metode stochastik (statistik). Selain itu, metode lain yang juga umum digunakan untuk proses prakiraan adalah teknik hitungan yang mengadopsi prinsip kerja dari sel syaraf manusia untuk mempelajari perilaku dari data sebelumnya. Jaringan syaraf tiruan propagasi balik (JSTPB) adalah salah satu varian dari teknik perhitungan tersebut. Metode ini telah umum digunakan untuk prakiraan cuaca dan parameter fisis lainnya. Penggunaan metode JSTPB di sebagian wilayah perairan Indonesia untuk memprediksi tinggi gelombang laut telah dilakukan oleh Bekalani (2013) [5]. Model arsitektur yang dibangun menunjukan nilai koefisien korelasi yang sangat baik di beberapa titik pengamatan wilayah perairan Selat Karimata. Parameter fisis ini sangat dipengaruhi oleh kondisi cuaca wilayah ekuator yang sangat dinamis. Selain itu, prakiraan parameter fisis cuaca dengan fluktuasi bulanan selama lima tahun (2013 - 2017) yang kompleks di Kota Pontianak menggunakan JSTPB menunjukkan nilai koefisien determinasi yang kuat sebesar 93,34\%, juga pernah dilakukan oleh Aprianto (2018) [6]. Selanjutnya, prediksi kondisi biometeorologi berdasarkan nilai physiologically equivalent temperature (PET) di lingkungan perkotaan Mediterania menggunakan JST model RayMan pernah dilakukan oleh Moustris (2013) [7]. Model JST yang dikembangkan memiliki nilai indeks evaluasi statistik yang signifikan $P<0,01$ 
yang berkemampuan untuk meramalkan nilai PET maksimum dan minimum harian, serta jumlah jam pada saat terjadi tekanan panas atau dingin yang ekstrim untuk hari berikutnya. Namun, berdasarkan ketiga informasi tersebut, arsitektur jaringan yang digunakan sangat bergantung pada kasus yang dihadapi.

Berdasarkan penjelasan sebelumnya, maka penelitian ini menggunakan JSTPB untuk memperkirakan fluktuasi suhu dan kelembapan udara di Kota Pontianak dan pada tahapan selanjutnya, hasil perkiraan JSTPB akan digunakan dalam perkiraan THI di Kota Pontianak. Indeks tersebut digunakan sebagai patokan tingkat kenyamanan oleh penduduk di Kota Pontianak. Dengan menghitung THI, distribusi kenyamanan dapat dipetakan secara spasial. Hasil dari perhitungan tersebut dapat digunakan untuk menentukan kebijakan terkait tata ruang/wilayah. Sebagai contoh pembangunan taman, pusat industri maupun perdagangan. Dengan demikian, pihak-pihak terkait dapat melakukan kajian yang nantinya akan menjadi dasar bagi kebijakan pengembangan kota di masa yang akan datang.

\section{Metodologi}

\subsection{Data}

Penelitian ini menggunakan data suhu udara (T) dan kelembapan relatif (RH) bulanan di Kota Pontianak selama 11 tahun (2009-2019). Kedua data tersebut diperoleh dari Europe Center for Medium Range Weather Forecasting (ECMWF) Era

\section{5} (https://cds.climate.copernicus.eu/\#!/home) dengan resolusi data sebesar $1 / 4^{\circ}$ dan batas geografi wilayah $0,25^{\circ} \mathrm{LU}-0,25^{\circ} \mathrm{LS}$ dan $109,25^{\circ} \mathrm{BT}$ - $109,75^{\circ}$ BT.

Kedua data ini akan dipisahkan dalam dua kelompok. Kelompok pertama digunakan sebagai data latih yang terdiri dari data 10 tahun pertama yaitu 2009-2018. Kelompok data ke dua yang terdiri dari data tahun 2019 digunakan sebagai verifikasi hasil prediksi JSTPB.

\subsection{Arsitektur Jaringan Saraf Tiruan}

Arsitektur JSTPB yang digunakan terdiri dari satu lapisan masukan, satu lapisan tersembunyi dan satu lapisan keluaran. Lapisan masukan terdiri dari dua belas neuron yang menyatakan banyaknya bulan dalam satu tahun. Lapisan keluaran hanya memiliki satu neuron. Pada lapisan tersembunyi, ada empat variasi jumlah neuron yang digunakan dalam penelitian ini yaitu sepuluh, dua puluh, tiga puluh, dan empat puluh neuron.

Pemberian variasi pada lapisan tersembunyi bertujuan untuk mendapatkan konfigurasi jaringan terbaik yang akan digunakan untuk proses prediksi. Pemilihan konfigurasi jaringan terbaik dilakukan dengan mencari nilai kesalahan terkecil dan indeks korelasi terbesar. Besarnya kesalahan dinyatakan dengan nilai Mean Square Error (MSE). Fungsi aktivasi yang digunakan pada lapisan tersembunyi adalah sigmoid biner (logsig). Pada lapisan keluaran digunakan fungsi aktivasi identitas (purelin).

\subsection{Prediksi THI}

Data hasil prediksi suhu dan kelembapan udara digunakan untuk menghitung indeks THI. THI dihitung menggunakan pers. (1).

$$
T H I=0,8 T+\left(\frac{R H \times T}{500}\right)
$$

Setelah perhitungan nilai THI, tingkat kenyamanan di suatu wilayah ditentukan berdasarkan klasifikasi di Tabel 1.

Tabel 1. Klasifikasi kenyamanan berdasarkan nilai THI

\begin{tabular}{|c|c|}
\hline $\begin{array}{c}\text { Nilai THI } \\
\left({ }^{\circ} \mathbf{C}\right)\end{array}$ & Kategori \\
\hline $21-24$ & $100 \%$ populasi merasakan nyaman \\
\hline $25-27$ & $50 \%$ populasi merasakan nyaman \\
\hline$>27$ & $\begin{array}{c}100 \% \text { populasi merasakan tidak } \\
\text { nyaman }\end{array}$ \\
\hline
\end{tabular}

Tingkat kenyamanan di Kota Pontianak digambarkan dalam bentuk peta yang dibuat menggunakan perangkat lunak QGIS. Pembuatan peta bertujuan untuk memberikan informasi spasial sebaran tingkat kenyamanan di Kota Pontianak.

\section{Hasil dan Pembahasan}

\subsection{Pelatihan dan Pengujian Jaringan Saraf Tiruan}

Pelatihan jaringan dilakukan untuk mengenali pola dan membentuk bobot - bobot terbaik hasil pelatihan dari arsitektur dan konfigurasi yang telah ditentukan sebelumnya. Tabel 2 dan Tabel 3 merupakan hasil dari pelatihan jaringan kelembapan udara dan suhu udara disemua model arsitektur pada bujur $109,25^{\circ} \mathrm{BT}$ dan lintang $0^{\circ} \mathrm{EQ}$. 
Tabel 2. Hasil Pelatihan Kelembapan Udara

\begin{tabular}{|c|c|c|c|}
\hline $\begin{array}{c}\text { Arsitektur } \\
\text { Jaringan }\end{array}$ & $\begin{array}{c}\text { Epoch } \\
\text { (iterasi) }\end{array}$ & $\mathbf{R}$ & MSE \\
\hline $12-10-1$ & 385 & 0,945339 & 0,003 \\
\hline $12-20-1$ & 899 & 0,935201 & 0,003 \\
\hline $12-30-1$ & 240 & 0,945227 & 0,003 \\
\hline $12-40-1$ & 312 & 0,948624 & 0,003 \\
\hline
\end{tabular}

Tabel 3. Hasil Pelatihan Suhu Udara

\begin{tabular}{|c|c|c|c|}
\hline $\begin{array}{c}\text { Arsitektur } \\
\text { Jaringan }\end{array}$ & $\begin{array}{c}\text { Epoch } \\
\text { (iterasi) }\end{array}$ & $\mathbf{R}$ & MSE \\
\hline $12-10-1$ & 941 & 0,956425 & 0,002 \\
\hline $12-20-1$ & 301 & 0,958598 & 0,002 \\
\hline $12-30-1$ & 452 & 0,965481 & 0,002 \\
\hline $12-40-1$ & 785 & 0,960033 & 0,002 \\
\hline
\end{tabular}

Tabel 2 dan 3, menjelaskan secara umum bahwa penerapan JSTPB pada masa latih telah memberikan hasil yang sangat baik dan memiliki korelasi yang sangat kuat. Hasil ini juga menunjukkan bahwa jumlah neuron pada lapisan tersembunyi memberikan hasil yang berbeda-beda dikarenakan adanya pengaruh perubahan nilai bobot disetiap lapisannya.
Tabel 4. Hasil Pengujian Kelembapan Udara

\begin{tabular}{|c|c|c|}
\hline $\begin{array}{c}\text { Arsitektur } \\
\text { Jaringan }\end{array}$ & $\mathbf{R}$ & MSE \\
\hline $12-10-1$ & 0,73406 & 0,025 \\
\hline $12-20-1$ & 0,71611 & 0,02581 \\
\hline $12-30-1$ & 0,70878 & 0,02509 \\
\hline $12-40-1$ & 0,90249 & 0,01078 \\
\hline
\end{tabular}

Tabel 5. Hasil Pengujian Suhu Udara

\begin{tabular}{|c|c|c|}
\hline $\begin{array}{c}\text { Arsitektur } \\
\text { Jaringan }\end{array}$ & $\mathbf{R}$ & MSE \\
\hline $12-10-1$ & 0,42928 & 0,02353 \\
\hline $12-20-1$ & 0,66143 & 0,032517 \\
\hline $12-30-1$ & 0,90699 & 0,00488 \\
\hline $12-40-1$ & 0,38207 & 0,0237 \\
\hline
\end{tabular}

Tabel 4 dan 5 memperlihatkan verifikasi dari hasil prediksi masing-masing arsitektur. Meskipun secara umum JSTPB memberikan hasil yang sangat baik pada saat proses pelatihan, namun tidak semua arsitektur memberikan hasil yang baik pada proses verifikasi. Hanya arsitektur 12-40-1 (kelembapan udara) dan 12-30-1 (untuk suhu udara) yang mampu memberikan hasil yang sangat baik. Hasil ini juga menunjukkan tingkat kerumitan dalam prediksi kelembapan dan suhu udara. Rendahnya nilai koefisien korelasi memperlihatkan bahwa pola temporal dari kedua variabel tersebut cukup rumit, terutama untuk suhu udara.

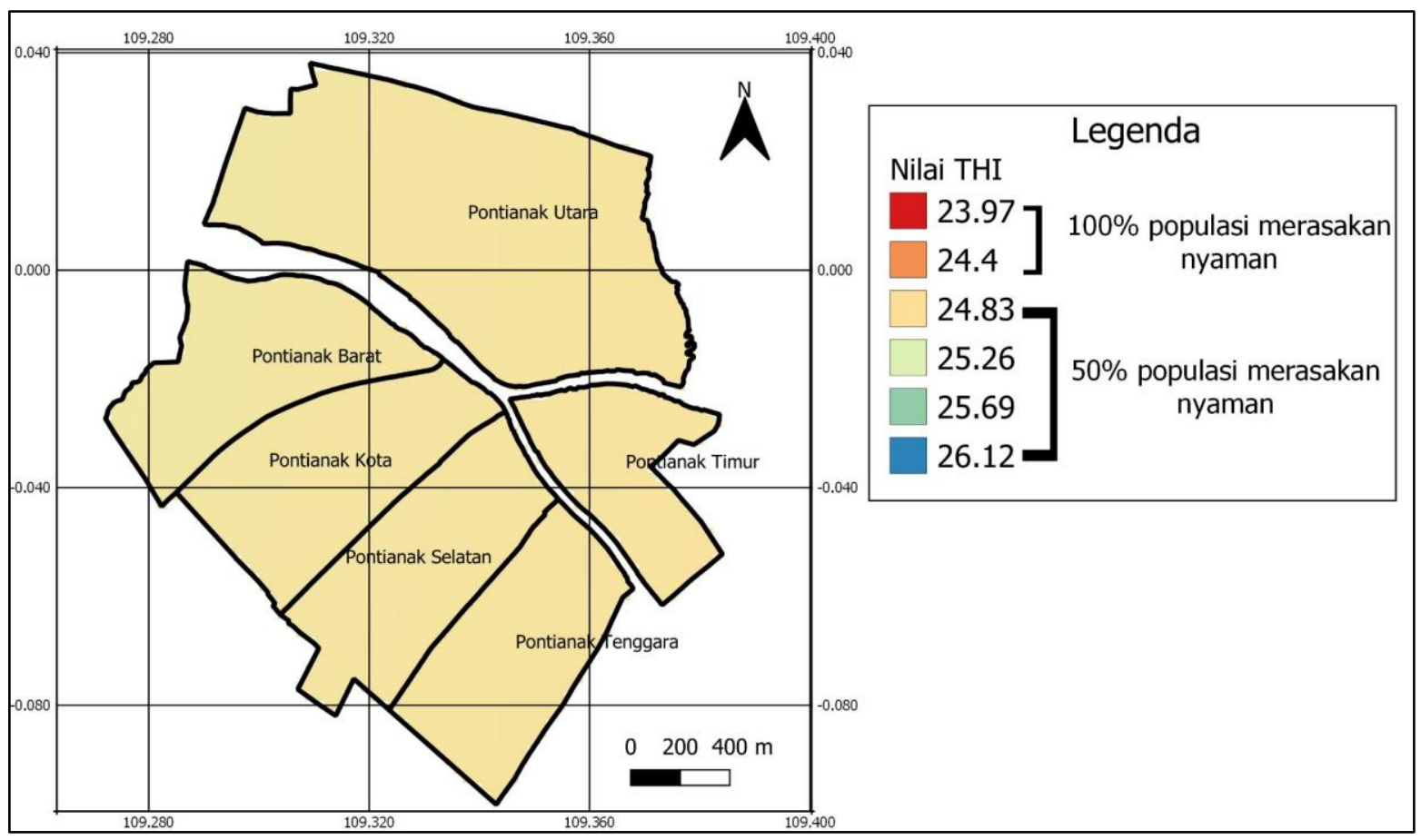

Gambar 1. Nilai rata - rata dari Tingkat Kenyamanan Termal di Kota Pontianak sepanjang tahun 2020 yang dinyatakan dalam THI 


\subsection{Prediksi THI di Kota Pontianak}

Distribusi spasial dari nilai THI hasil prediksi menggunakan JSTPB diperoleh melalui proses interpolasi data untuk wilayah kota Pontianak. Pada Gambar 1. terlihat Kota Pontianak memiliki nilai THI rata-rata sepanjang tahun 2020 sebesar 24,83 . Keadaan tersebut mengindikasikan bahwa sebanyak $50 \%$ warga yang berada di wilayah Kota Pontianak pada tahun 2020 akan merasakan kondisi termal yang nyaman.

Tingkat kenyamanan termal di Kota Pontianak pada tahun 2020 sangat bervariasi disetiap bulannya, hal tersebut dipengaruhi oleh intensitas curah hujan yang berubah-ubah disetiap bulannya. Pada saat hujan suhu udara dan kelembapan udara cenderung lebih tinggi karena adanya penguapan [8]. Dapat dilihat pada Gambar 2. bahwa prediksi THI yang dihasilkan disepanjang tahun 2020 ini menunjukan bahwa $100 \%$ populasi yang berada di wilayah Pontianak akan merasa nyaman pada bulan Juni, Agustus, Oktober, dan puncaknya pada bulan Desember. Sebaliknya, tingkat kenyamanan termal terendah terjadi pada bulan Januari di awal tahun 2020. Menurut kajian yang menyatakan bahwa

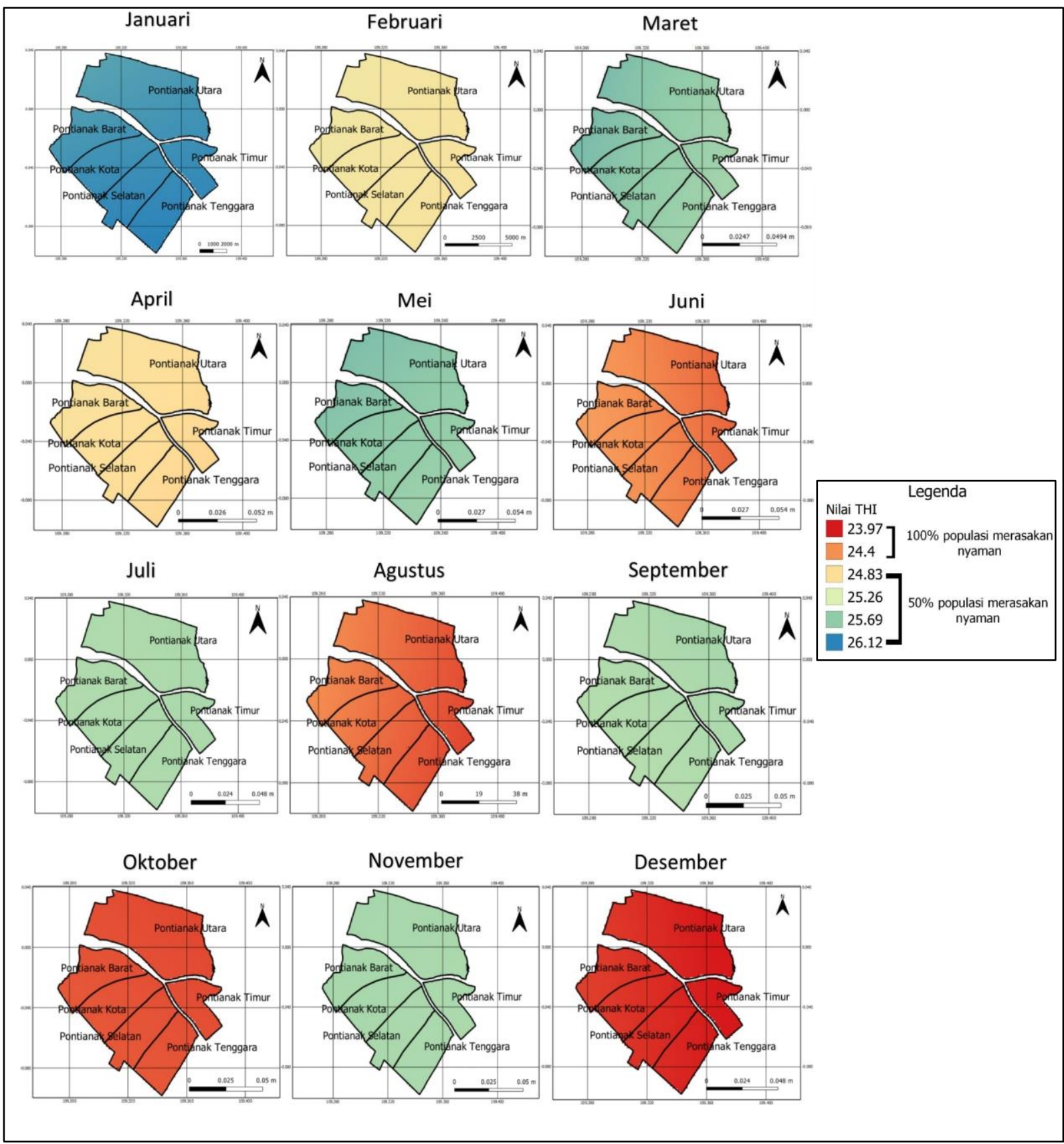

Gambar 2. Tingkat Kenyamanan Termal di Kota Pontianak pada setiap bulan di tahun 2020 yang dinyatakan dalam THI. 
kenyamanan akan semakin besar jika berada semakin jauh dari pusat kota [4], namun pernyataan tersebut tidak berlaku untuk daerah

\section{Kesimpulan}

Berdasarkan hasil penelitian yang telah dilakukan, maka diperoleh kesimpulan yaitu pengujian JSTPB memperoleh korelasi yang berkategori "sangat kuat" dengan nilai 0,90429 untuk kelembapan udara dan 0,90699 untuk suhu udara. Tingkat kenyamanan Termal di Kota Pontianak berdasarkan THI memiliki 4 bulan dalam kategori $100 \%$ populasi merasakan nyaman yaitu pada bulan Juni, Agustus, Oktober, dan Desember. Rata - rata tahunan THI sebesar $24,83^{\circ} \mathrm{C}$ yang berkategori $50 \%$ populasi merasakan nyaman.

\section{Ucapan Terima Kasih}

Terimakasih kepada Laboratorium Komputer Terpadu Universitas Tanjungpura yang telah bersedia meminjamkan komputer sebagai tempat pengolahan data menggunakan Matlab 2019.

\section{Daftar Pustaka}

[1] Kalfuadi, Y., Analisis Temperature Humidity Index (THI) Dalam Hubungannya dengan Ruang Terbuka Hijau, Skripsi, FMIPA, IPB, Bogor, 2009.

[2] Emmanuel, R., Thermal Comfort Implications of Urbanization in a Warm-humid City: The Colombo Metropolitan Region (CMR), Sri Lanka, J Building and Evironment, 40, pp. 1591- 1601, 2005.

[3] Marsitha, F.; Wendel, J.P dan Rista, H. V., Kenyamanan Termal Klimatologis Kota - Kota Besar Sulawesi Berdasarkan Temperature Humidity Index (THI), Jurnal Saintika UNPAM, 1, 2019.

[4] Wati, T. \& Fatkhuroyan., Analisis Tingkat Kenyamanan Di DKI Jakarta Berdasarkan Indeks THI (Temperature Humidity Index), Jurnal Ilmu Lingkungan, 15, PP. 57-63. 2017.

[5] Bekalani, A. I.; Arman, Y., dan Jumarang, M. I., Prediksi Tinggi Signifikan Gelombang Laut Di
Sebagian Wilayah Perairan Indonesia Menggunakan Jaringan Syaraf Tiruan Metode Propagasi Balik, PRISMA FISIKA, 1(1), pp. 4049, 2013.

[6] Aprianto, Y.; Nurhasanah., dan Sanubary, I., Prediksi Kadar Particulate Matter ( $\left.\mathrm{PM}_{10}\right)$ untuk Pemantauan Kualitas Udara Menggunakan Jasringan Syaraf Tiruan Studi Kasus Kota Pontianak, POSITRON, 8(1), pp. 1520, 2018.

[7] Moustris, K. P.; P. T. Nastos., dan A. G. Paliatos., One-Day Prediction of Biometeorological Conditions in a Mediterranean Urban Environment Using Artificial Neural Networks Modeling, Hindawi Publishing Corporation, 2013.

[8] Kurnia, Ridwan F.A., Analisis Indeks Kenyamanan Iklim, Skripsi, Departemen Geofisika dan Meteorologi, Institut Pertanian Bogor, Bogor, 2016. 